\title{
PROADRENOMEDULIN AS A PREDICTOR OF MORTALITY IN MAJOR NON-CARDIAC SURGERY
}

\author{
Mlađan Golubović1, Vladan Cvetanović ${ }^{1}$, Nenad Jovanović ${ }^{1}$

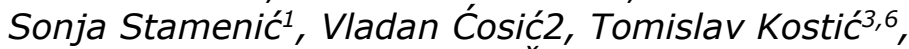 \\ Zoran Damnjanovićc ${ }^{4,6}$, Sandra Šarić5, Maša Golubović6, \\ Viktor Stoičkov ${ }^{5,6}$
}

\begin{abstract}
Anesthesiologists are in daily contact with patients who are preparing for noncardiosurgical interventions, and who have an increased risk of developing cardiovascular complications in the perioperative period. Less than $1 \%$ of patients develop perioperative IM, however the mortality rate for this complication ranges from $30 \%$ to $50 \%$. The first step is the identification of patients in whom the cardiovascular system is a potential source of complications during and after surgery. The risk of perioperative complications depends on the condition of the patient prior to the intervention, prevalence of comorbidities and the extent, urgency and duration of the operation.

The modern concept of preoperative preparation of patients for major non-cardiac surgery is now based on the measurement and interpretation of various biomarkers as prognosticators of perioperative cardiovascular complications and fatal outcomes. For these purposes, high-performance natriuretic peptides and cardiac troponins are used. There is evidence that the levels of cardiac-specific troponins, and especially highsensitivity troponin $\mathrm{T}(\mathrm{hs}-\mathrm{TnT})$, have been elevated in patients with various cardiovascular diseases such as: cardiac insufficiency and coronary disease, reflecting in this way a lower degree of damage that can be of significant benefit in the preoperative assessment of cardiovascular morbidity and mortality in elective, major non-cardiac surgery. Although various natriuretic peptides have been in the greatest focus of interest as prognostic biomarkers over the past decade, the interest in other circulating biomarkers, such as midregional proadrenomedulin (MR-pro ADM), has been growing in recent years.

This new biomarker represents a stable circulating peptide, and is the prohormone of adrenomedulin, a hormone responsible for regulating the volume of circulating fluid and electrolyte homeostasis. Elevated levels of this biomarker are seen in heart failure of different etiologies and can therefore serve as a useful prognostic marker of the development of perioperative cardiovascular complications in patients with different cardiovascular comorbid conditions.
\end{abstract}

Acta Medica Medianae 2017;56(4):11-16.

Key words: proadrenomedulin, non cardiac surgery, biomarkers

\footnotetext{
${ }^{1}$ Clinical Center Niš, Department for anesthesiology and reanimatology, Niš, Serbia

${ }^{2}$ Clinical Center Niš, Center for medical biochemistry, Niš, Serbia

${ }^{3}$ Clinical Center Niš, Clinic for cardiovascular diseases, Niš. Serbia

${ }^{4}$ Clinical Center Niš, Clinic for cardiovascular and

transplantation surgery, Niš, Serbia

Institute for treatment and rehabilitation "Niška Banja", Niš, Serbia

${ }^{6}$ University of Niš, Medical Faculty Niš, Serbia

Contact: Mlađan Golubović

Bul. Zoran Đinđića 48, 18000 Niš, Srbija

E-mail: mladjangolubovic@gmail.com
}

Adrenomedullin (ADM) is a peptide with a rapid clearance from the circulation and a short half-life (22 minutes) and its use as a routine biomarker is not practical. Midregional proadrenomedullin (MR-proADM) is released in higher concentrations than ADM; it is inactive and has a longer half-life; therefore, it represents a suitable substitute (1-3).

The MR-proADM molecule is secreted from rat cardiomyocytes and in the heart tissue there are specific binding places for MR-proADM. One of its functions is that it is included in the control of coronary vascular tone. The level of MR-proADM is elevated in the patients with essential hypertension and congestive heart failure $(2,3)$.

Due to its stability and specificity, MRproADM is a significant biomarker for the predic-

\section{Introduction}


tion of heart damage since it is basically a biomarker of endothelial dysfunction. The level of MR-proADM is elevated in the patients with heart diseases, such as congenital heart failure, ischaemic heart disease, and atherosclerosis. It also represents a significant predictor of mortality in these individuals (4).

Perioperative major cardiovascular events (PMCE), such as acute myocardial infarction, pulmonary oedema or primary cardiovascular death, are important causes of morbidity in pa-tients undergoing a major non-cardiac surgery (5). A number of clinical risk indices using a sco-ring system have been developed, but their predictive power is still insufficient (6-9). Perioperative risk can be estimated based on the severity of existing heart failure, development of recent myocardial infarction, arrhythmias, presence of aortic stenosis, patient age, type of planned surgery, chronic obstructive pulmonary disease, renal function, previous transient ischemic attacks, general condition of the patient, etc. (10). We hypothesized that the pathophysiology of a cardiovascular disease, including inflammation, myocardial ischaemia or increased ventricular filling pressures, could be important in the development of PMCE. Cardiovascular biomarkers that could reflect this pathophysiology would therefore be useful for the prediction of perioperative risk (11). Biomarkers also have a great role in improving the treatment of heart diseases and monitoring of the effectiveness of therapy $(12,13)$. We investigated the predictive power of preoperative values of midregional proadrenomedulin (MR-pro ADM) for perioperative cardiovascular risk prior to elective major non-cardiac surgery.

The main objective of this study was to determine the utility of preoperative MR- proADM monitoring. We expected circulating levels of MRproADM to be significantly elevated preoperatively in the group of patients with cardiovascular risks, such as hypertension, diabetes mellitus, hyperlipidemia, family history of cardiovascular disease and some active smokers, compared to those with no risk factors undergoing a major non-cardiac surgery.

\section{Material and methods}

This prospective, single-center, observational study enrolled 81 patients undergoing major non-cardiac surgery. A total of 81 patients were recruited between September and December 2013 at the Surgical Clinics in Clinical Center Niš, Serbia. The inclusion criteria were major non-cardiac surgery (abdominal, thoracical, orthopaedic and vascular) in general anaesthesia, age of 55 years and at least one of the following cardiovascular risk factors - diabetes mellitus, hypertension, hyperlipidaemia, active smoking, or a family history of cardiac disease. The exclusion criteria were emergency surgery and an inability to understand or to sign the informed consent.

All the patients included into the study signed the informed consent, which included biomarker analyses. The study has been approved by the Ethical Committee of the Faculty of Medicine, University of Niš.

The patients undergoing major non-cardiac surgery were included. The planned procedures had to be performed under general anaesthesia. Surgical procedures were performed according to clinical standards. Blood samples were taken within 48 hours prior to surgery. Samples were taken from an antecubital vein in tubes without additives and processed immediately. The sera were separated and frozen at $-80^{\circ} \mathrm{C}$ until analyses. MR-pro ADM was measured using the novel assays provided by Thermo Fisher/B.R.A.H.M.S GmbH (Hennigsdorf, Germany).

\section{Results}

Demographic and clinical characteristics of the tested population

The study included 81 patients (42 women 51. $90 \%$ and 39 men $-48.10 \%)$. Their average age was $71.30 \pm 6.62$ years (min 51 years, max 87.00 years). Within 14 days, 14 patients died in the tested population (17.30\%). Among the deceased patients, 6 were men $(42.90 \%)$ and 8 were women $(57.10 \%)$. It was found that there was no statistically significant difference in gender with respect to fatal outcomes ( $p=0.887)$. The examination of demographic and clinical characteristics showed that there was no statistically significant difference in any of the tested parameters with respect to fatal outcomes (Table 1 ).

The concentration of proADM was statistically significantly higher in the deceased patients, compared to the survivors ( $p<0.001)$.

All the patients who died were in intensive care units $(100,00 \%)$ and the group of the survivors consisted of 50 patients $(74.60 \%)$. The patients who died had been statistically significantly more often admitted to intensive care units (Fisher's test $p=0.034$ ).

The average number of days spent in intensive care units for the deceased was 5.29 \pm 3.65 days ( $\min 1$ day, max 12 days) and with the survivors it was $2.21 \pm 1.75$ days (min 0 days, $\max 6$ days). It was found that the deceased patients had statistically significantly more days in intensive care units ( $z=2.982, p=0.003$ )

Based on the border values of proADM, the patients were classified into two groups: those with values below or equal to 0.80 , and those with marker values above 0.80 (Table 2). The KaplanMeier survival curve was constructed and it showed that patients with proADM values above the border value had statistically significantly shorter survival ( $p=0.001)$ (Graph1). 
Table 1. Demographic and clinical characteristics in relation to fatal outcome:

\begin{tabular}{|c||c|c|c|c|}
\hline Parameter & $\begin{array}{c}\text { Deceased } \\
\mathrm{N}=14\end{array}$ & $\begin{array}{c}\text { Survivors } \\
\mathrm{N}=67\end{array}$ & $\mathrm{p}$ \\
\hline \hline Gender (M/F) & $6 / 8$ & $33 / 34$ & 0,020 & 0,887 \\
\hline Age & $73,86 \pm 6,63$ & $70,76 \pm 6,54$ & 1,593 & 0,128 \\
\hline Previous IM & 0 & $1(1,50)$ & & $0,827^{*}$ \\
\hline Previous PCI & 0 & $2(3,00)$ & & $0,682^{*}$ \\
\hline Atrial fibrillation & $1(7,10)$ & $9(13,40)$ & 0,042 & $0,838 \mathrm{R}$ \\
\hline Previous stroke & 0 & $5(7,50)$ & & $0,377^{*}$ \\
\hline Peripheral arterial disease & 0 & $1(1,50)$ & & $0,827 *$ \\
\hline Liver diseases & $2(14,30)$ & $2(3,00)$ & 1,203 & 0,273 \\
\hline Lung diseases & $2(14,30)$ & $7(10,40)$ & 0,173 & 0,390 \\
\hline Tumor & $9(64,30)$ & $31(46,30)$ & 0,869 & 0,351 \\
\hline Metabolic disorders & 0 & $9(13,40)$ & & $0,164 *$ \\
\hline Cardiovascular risk factors & $14(100,00)$ & $66(98,50)$ & & 0,827 \\
\hline Hypertension & $10(71,40)$ & $54(80,60)$ & 0,164 & 0,685 \\
\hline Hyperlipidemia & $2(14,30)$ & $11(16,40)$ & & $0,603 *$ \\
\hline Diabetes mellitus (DM) & $3(21,40)$ & $20(29,90)$ & 0,096 & 0,757 \\
\hline Insulin dependent DM & 0 & $6(9,00)$ & 0,363 & 0,547 \\
\hline Family history & $9(64,30)$ & $35(52,20)$ & 0,279 & 0,597 \\
\hline Active smoking status & $1(7,10)$ & $11(16,40)$ & 0,226 & 0,635 \\
\hline
\end{tabular}

Table 2. The Kaplan-Meier curve parameters in relation to border values of proADM

\begin{tabular}{|c||c|c|c|c|c|c|}
\hline Parameter & & Median & SE & $95 \% C I$ & $X^{2}$ & $p$ \\
\hline \hline proADM & $\leq 0,80$ & 17,71 & 0,23 & $17,33-18,22$ & 11,730 & 0,001 \\
\hline & $>0,80$ & 15,00 & 4,15 & $6,87-23,13$ & & \\
\hline
\end{tabular}

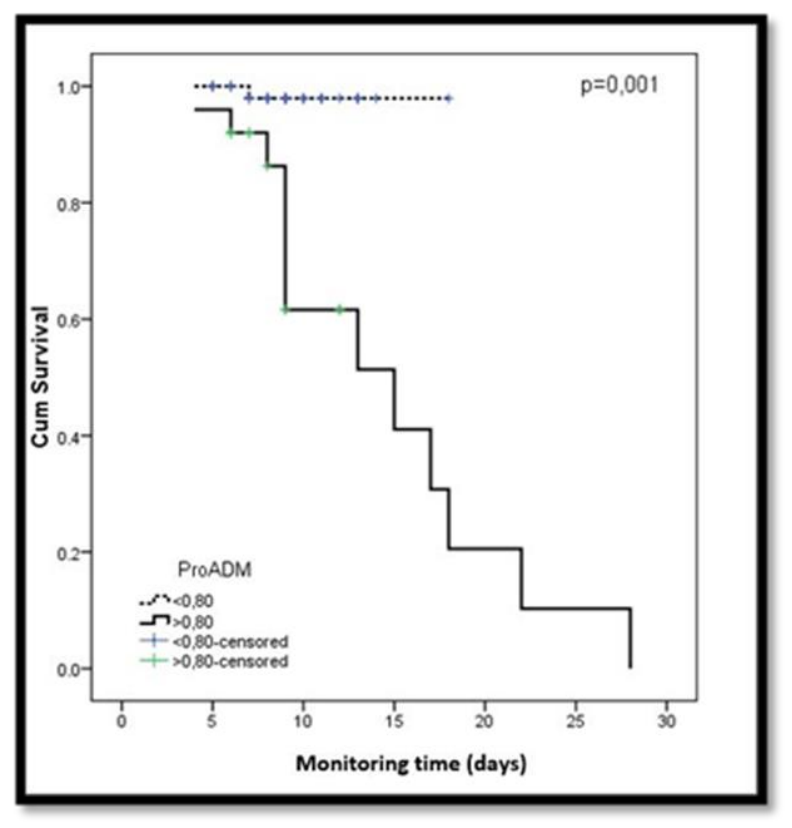

Graph 1. The Kaplan-Meier survival curve in relation to border proADM values:

\section{Discussion}

In the present study, we aimed to analyse the additive value of MR-proADM to identify the patients at a high risk for adverse cardiac events among those undergoing major non-cardiac surgery. Pre-operative risk assessment is of great clinical importance. In most cases, non-cardiac surgery is performed as an elective procedure, allowing a thorough investigation of the patient and accurate risk evaluation in order to indicate a surgical procedure.

Smith et al. have shown that MR-proADM, CRP, and NT-pro-BNP are good predictors of the onset of heart failure and that they are completely independent of other biomarkers and risk factors (14). The combination of MR-proADM and Nt-proBNP is suggested for the mortality prediction (15, 16). It has been examined whether a panel of biomarkers (PCT, MR-proADM, CT-pro-endothelin1 , CT-pro-arginine vasopressin, and MR-pro-ANP), each of them separately or using the Acute Physiology and Chronic Health Evaluation IV score, has a greater significance in the prediction of intrahospital mortality. It has been shown that MR-proADM has the greatest significance in the first 6 to 18 hours after entering the ICU, even when its significance has been compared to the Acute Physiology and Chronic Health Evaluation IV score in elective cardiosurgery (17).

Recently published BACH (Biomarkers in Acute Heart Failure) study pointed out that MRproADM has a much greater significance than BNP in the mortality prognosis within 90 days in 
patients with diagnosed acute heart failure (18, 19). This supports the superiority of MR-proADM compared to NTpro-BNP and BNP in the prediction of mortality within 14 days $(20,21)$.

A comparative analysis of 12 biomarkers showed that NTpro-BNP, GDF-15, MR-proADM, cystatin $C$, and MR-pro-ANP are the strongest predictors of cardiovascular complications in patients with stable angina pectoris, alone and in combination (22). In their study, Weber at al. were able to demonstrate that the assessment of high sensitivity troponin $\mathrm{T}$ (hs TnT) added incremental prognostic information to the established revised cardiac index (Lee index) and NT-proBNP (23).

\section{Conclusion}

Preoperative prediction of cardiovascular risk in patients who are preparing for non-cardiac surgery is essential. New protocols have confirmed that biomarkers have a significant role in that. The present increased availability of novel markers for cardiovascular risk warrants a systematic approach in establishing their value for the clinical management of individual patients. We believe that an organized approach to the development and critical appraisal of novel risk markers will contribute to the improved clinical management of patients at risk of cardiovascular disease.

\section{References}

1. Landman GW, van Dijk PR, Drion I, van Hateren KJ, Struck J, Groenier $\mathrm{KH}$, et al. Midregional fragment of proadrenomedullin, new-onset albuminuria, and cardiovascular and all-cause mortality in patients with Type 2 Diabetes (ZODIAC-30). Diabetes Care 2014; 37(3): 839- 45. [CrossRef][PubMed]

2. Kaygisiz $Z$, Ozden $H$, Erkasap $N$, Köken $T$, Gündüz $T$, Ikizler $M$, et al. Effects of proadrenomedullin $N$ terminal 20 peptide and calcitonin on isolated perfused rat hearts. Anadolu Kardiyol Derg 2009; 9(3):176-82. [PubMed]

3. Loncar G, Omersa D, Cvetinovic N, Arandjelovic A, Lainscak M. Emerging biomarkers in heart failure and cardiac cachexia. Int J Mol Sci 2014; 15(12): 23878-96. [CrossRef][PubMed]

4. Eggers KM, Venge $P$, Lindahl $B$, Lind L. Associations of mid-regional pro-adrenomedullin levels to cardiovascular and metabolic abnormalities, and mortality in an elderly population from the community. Int J Cardiol 2013; 168(4): 3537-42. [CrossRef][PubMed]

5. Tsuruda T, Kato J, Kitamura K, Kuwasako K, Imamura $T$, Koiwaya $Y$, et al. Secretion of proadrenomedullin $\mathrm{N}$-terminal 20 peptide from cultured neonatal rat cardiac cells. Life Sci 2001; 69(2): 239-45. [CrossRef][PubMed]

6. Devereaux PJ1, Goldman L, Cook DJ, Gilbert K, Leslie K, Guyatt GH. Perioperative cardiac events in patients undergoing noncardiac surgery: a review of the magnitude of the problem, the pathophysiology of the events and methods to estimate and communicate risk. CMAJ 2005; 173(6): 627-34. [CrossRef][PubMed]

7. Goldman L, Caldera DL, Nussbaum SR, Southwick FS, Murray B, et al. Multifactorial index of cardiac risk in noncardiac surgical procedures. $N$ Engl J Med 1977; 297(16): 845-50. [CrossRef][PubMed]
8. Detsky AS, Abrams HB, Forbath N, Scott JG, Hilliard JR. Cardiac assessment for patients undergoing noncardiac surgery. A multifactorial clinical risk index. Arch Intern Med 1986; 146(11): 2131-4. [CrossRef][PubMed]

9. Lee TH, Marcantonio ER, Mangione CM, Thomas EJ, Polanczyk CA, Cook EF, et al. Derivation and prospective validation of a simple index for prediction of cardiac risk of major noncardiac surgery. Circulation 1999; 100(10): 1043-9. [CrossRef][PubMed]

10. Kertai MD, Boersma E, Klein J, van Sambeek M, Schouten $\mathrm{O}$, van Urk $\mathrm{H}$, et al. Optimizing the prediction of perioperative mortality in vascular surgery by using a customized probability model. Arch Intern Med 2005; 165(8): 898-904. [CrossRef][PubMed]

11. Jankovic R, Markovic D, Savic N, Dinic V. Beyond the limits: Clinical utility of novel biomarkers. Biomed Res Int 2015; ArticleID 187384. [PubMed]

12. Jankovic R, Zdravkovic I, Markovic D. Role of biomarkers in cardiac risk assessment for noncardiac surgery. Proceedings of the XII Serbian Congress of Anesthesiologists and Intensivits; 2014 Oct 23-16; Belgrade,Serbia. P.22-5.

13. Iqbal N, Wentworth B, Choudhary R, Landa Ade L, Kipper B, Fard A, et al. Cardiac biomarkers: new tools for heart failure management. Cardiovasc Diagn Ther 2012; 2(2): 147-64. [PubMed]

14. Smith JG, Newton-Cheh C, Almgren P, Struck J, Morgenthaler NG, Bergmann A, et al. Assessment of conventional cardiovascular risk factors and multiple biomarkers for the prediction of incident heart failure and atrial fibrillation. J Am Coll Cardiol 2010; 56(21): 1712-9. [CrossRef][PubMed]

15. von Haehling $S$, Jankowska EA, Morgenthaler NG, Vassanelli C, Zanolla L, Rozentryt P, et al. Comparison of midregional pro-atrial natriuretic 
peptide with $\mathrm{N}$-terminal pro-B-type natriuretic peptide in predicting survival in patients with chronic heart failure. J Am Coll Cardiol 2007; 50(20): 1973-80. [CrossRef][PubMed]

16. von Haehling S, Filippatos GS, Papassotiriou J, Cicoira M, Jankowska EA, Doehner W, et al. Midregional pro-adrenomedullin as a novel predictor of mortality in patients with chronic heart failure. Eur J Heart Fail 2010;12(5): 484-91. [CrossRef][PubMed]

17. Schoe A, Schippers EF, Struck J, Ebmeyer S, Klautz $R J$, de Jonge $E$, et al. Postoperative proadrenomedullin levels predict mortality in thoracic surgery patients: comparison with Acute Physiology and Chronic Health Evaluation IV Score. Crit Care Med 2015; 43(2): 373-81. [CrossRef] [PubMed]

18. Maisel A, Mueller C, Nowak RM, Peacock WF, Ponikowski $P$, Mockel $M$, et al. Midregion prohormone adrenomedullin and prognosis in patients presenting with acute dyspnea: results from the BACH (Biomarkers in Acute Heart Failure) trial. J Am Coll Cardiol 2011; 58(10): 1057-67. [CrossRef][PubMed]
19. Maisel A, Mueller C, Nowak R, Peacock WF, Landsberg JW, Ponikowski $P$, et al. Mid-region prohormone markers for diagnosis and prognosis in acute dyspnea: results from the BACH (Biomarkers in Acute Heart Failure) trial. J Am Coll Cardiol 2010; 55(19): 2062-76. [CrossRef][PubMed]

20. Potocki M, Ziller $R$, Mueller C. Mid-Regional proadrenomedullin in acute heart failure: a better biomarker or just another biomarker. Curr Heart Fail Rep 2012; 9(3): 244-51. [CrossRef][PubMed]

21. W. F. Peacock. Novel biomarkers in acute heart failure: MR-pro-adrenomedullin. Clin Chem Lab Med. 2014; 52(10): 1433-5. [CrossRef][PubMed]

22. Schnabel RB, Schulz A, Messow CM, Lubos E, Wild $\mathrm{PS}$, Zeller $\mathrm{T}$, et al. Multiple marker approach to risk stratification in patients with stable coronary artery disease. Eur Heart J 2010; 31(24): 3024-31. [CrossRef][PubMed]

23. Weber $M$, Luchner $A$, Seeberger $M$, Mueller $C$, Liebetrau $C$, Schlitt $A$, et al. Incremental value of high-sensitive troponin $T$ in addition to the revised cardiac index for perioperative risk stratification in non-cardiac surgery. Eur Heart J 2013; 34(11): 853-62. [CrossRef][PubMed] 


\title{
PROADRENOMEDULIN KAO PREDIKTOR MORTALITETA U VELIKIM NE-KARDIOHIRURŠKIM INTERVENCIJAMA
}

\author{
Mlađan Golubović ${ }^{1}$, Vladan Cvetanović ${ }^{1}$, Nenad Jovanović ${ }^{1}$, \\ Sonja Stamenić1, Vladan Ćosić2, Tomislav Kostić3,6, \\ Zoran Damnjanovićt ${ }^{4,6}$, Sandra Šarićs, Maša Golubović6, \\ Viktor Stoičkov ${ }^{5,6}$
}

\author{
${ }^{1}$ Klinički centar Niš, Centar za anesteziologiju i reanimatologiju Niš, Srbija \\ ${ }^{2}$ Klinički centar Niš , Centar za medicinsku biohemiju Niš, Srbija \\ ${ }^{3}$ Klinički centar Niš, Klinika za kardiovaskularne bolesti Niš, Srbija \\ ${ }^{4}$ Klinički centar Niš, Klinika za kardiovaskularnu i transplantacionu hirurgiju Niš, Srbija \\ "Institut za lečenje i rehabilitaciju " Niška Banja", Niška Banja, Srbija \\ "Univerzitet u Nišu, Medicinski fakultet Niš, Srbija
}

Kontakt: Mlađan Golubović

Bul. Zoran Đinđića 48, 18000 Niš, Srbija

E-mail: mladjangolubovic@gmail.com

Anesteziolozi su u svakodnevnom kontaktu sa pacijentima koji se pripremaju za nekardiohirurške intervencije, a koji imaju povišeni rizik za razvoj kardiovaskularnih komplikacija u perioperativnom periodu. Manje od $1 \%$ bolesnika razvije perioperativni IM, međutim, stopa mortaliteta kod ove komplikacije se kreće između 30 i 50\%. Prvi korak je identifikacija bolesnika kod kojih je kardiovaskularni sistem potencijalni uzrok komplikacija u toku i nakon operacije. Rizik perioperativnih komplikacija zavisi od stanja bolesnika pre intervencije, prevalencije komorbiditeta kao i od opsežnosti, hitnosti i trajanja operacije.

Moderni koncept preoperativne pripreme bolesnika za velike nekardiohirurške intervencije, danas se zasniva na merenju i interpretaciji različitih biomarkera kao prognostikatora perioperativnih kardiovaskularnih komplikacija i smrtnog ishoda. $U$ te svrhe se sa velikom uspešnošću koriste natriuretični peptidi i srčani troponini.

Postoje dokazi da su nivoi kardio specifičnih troponina, a naročito visoko senzitivnog troponina (high-sensitive troponin $\mathrm{T}$ - hs-TnT), povišeni kod bolesnika sa različitim kardiovaskularnim bolestima poput: srčane insuficinecije i koronarne bolesti, reflektujući na taj način i manji stepen oštećenja, što može biti od značajne koristi u preoperativnoj proceni kardiovaskularnog morbiditeta i mortaliteta kod elektivnih, velikih nekardiohirurških intervencija.

Iako su kao prognostički biomarkeri tokom poslednje dekade različiti natriuretični peptidi bili u najvećem fokusu interesovanja, poslednjih godina raste interesovanje za ulogu drugih cirkulišućih biomarkera poput midregionalnog proadrenomedulina (MR-pro ADM). Ovaj novi biomarker predstavlja stabilni cirkulišući peptid, i prohormon je adrenomedulina, hormona odgovornog za regulisanje volumena cirkulišuće tečnosti $i$ homeostazu elektrolita. Povišeni nivoi ovog biomarkera viđaju se kod srčane slabosti različite etiologije, stoga mogu poslužiti kao koristan prognostički marker nastanka perioperativnih kardiovaskularnih komplikacija kod bolesnika sa različitim kardiovaskularnim komorbitetima.

Acta Medica Medianae 2017;56(4):11-16.

Ključne reči: proadrenomedulin, nekardiohirurške intervencije, biomarkeri 